Such a facility would need to be endowed or sponsored, to guarantee its continuity. IUCN has very limited endowment, and depends for its financial balance on year-to-year fund-raising. This is not a satisfactory arrangement for a long-term facility such as the one discussed in this memorandum. Accordingly, it is suggested that the creation of a World Conservation Archive and a World Conservation Library should be the subject of bequest, donation, or sponsorship, by a patron or patrons whose names (or the names of those who they might prefer to see associated) would of course be attached to the facility.

MARTIN W. HoldGATE, Director General
IUCN/UICN
Avenue du Mont-Blanc
I196 Gland
Switzerland.

\title{
Garbage Dump in the Marshall Islands?
}

Far away, in the central-western Pacific Ocean, is a tiny and little-known, but remarkable and indeed unique, island. It is an uninhabited coral atoll, called in Marshallese 'Pokak' or 'Bokak' (on charts it is marked 'Taongi') (Fig. 1). It is the northernmost island of the vast Marshall Archipelago (Fig. 2), and is about 14 by 4 miles ( 22.5 by $6.4 \mathrm{~km}$ ) in dimensions, crescent-shaped, with a reef broken only by one narrow outlet from a rather shallow lagoon with many patch-reefs. On the southeastern curve of the outer reef of the crescent are a string of dry islets, with sparse but interesting vegetation, including one almost-endemic grass species. It is the only known coral atoll where the sea, driven by the trade-winds, pours in over the windward reef, and flows out in one narrow channel through the reef, maintaining a constant level in the lagoon.

The most spectacular feature, however, is the presence, on these islets, of what may be the largest sea-bird 'rookery' in the world. When the birds are frightened and fly up, they blacken the sky - millions of birds! Vast numbers of sooty and a half-dozen other species of terns nest there; sandflats are honeycombed and riddled with burrows of wedgetailed and Christmas-Island shearwaters, tropic-birds, three species of boobies, piratical frigate-birds that pursue

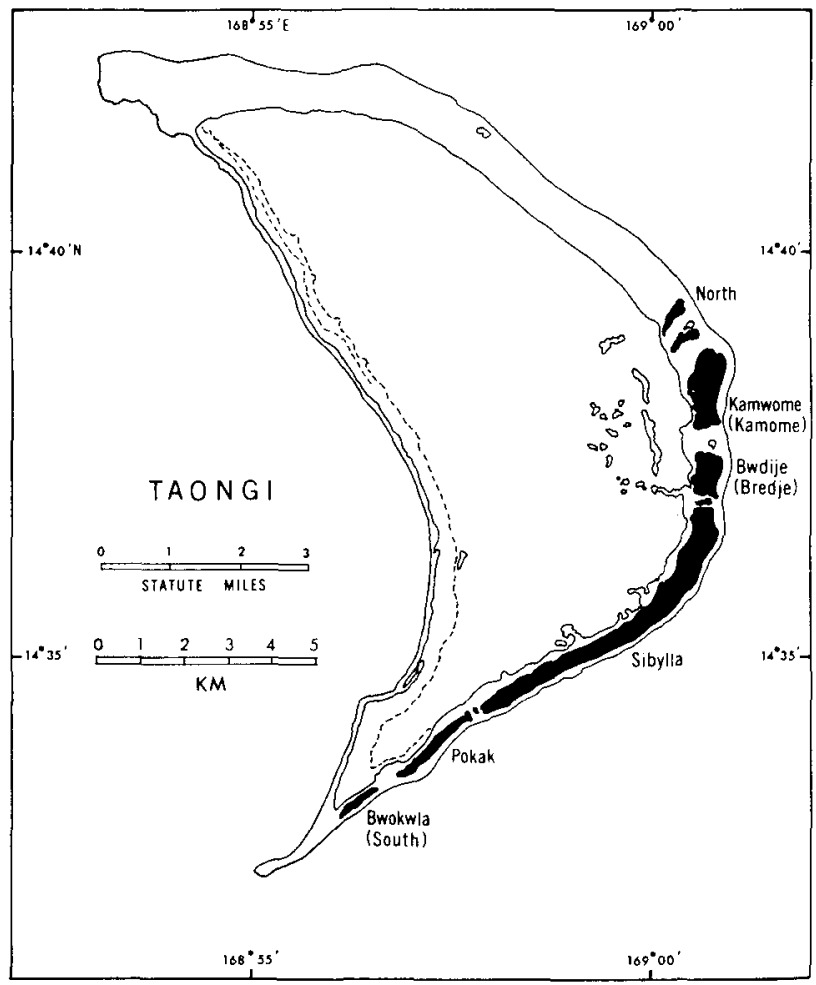

FIG. 1. Map of Taongi.

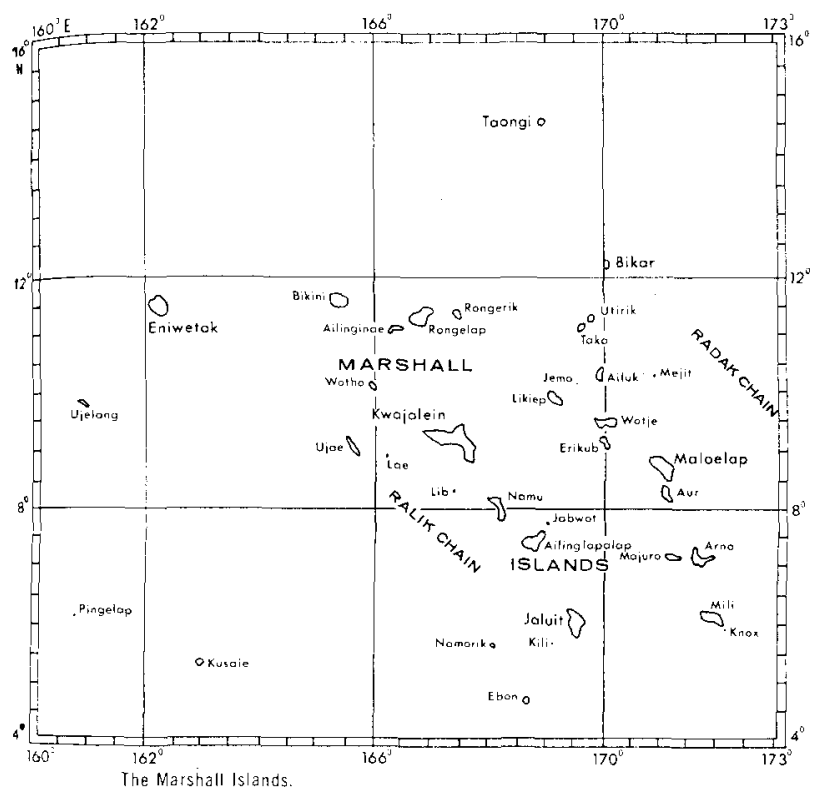

Fig. 2. Map of the Marshall Islands.

the boobies and steal their fish-all share these tiny pieces of land as well as the fishes of the lagoon and the waters around the island. In addition there are reef-herons, curlews, turnstones, golden plovers, wandering tattlers, and other shorebirds, migrants from north and south. Albatrosses have been seen in the vicinity.

Many smaller land-animals, insects, crustaceans, and spiders, abound. In addition to the land animals and vegetation, there are rich marine fauna and flora. Many species of corals and coralline Algae have built spectacular reefs, inhabitated by myriads of beautiful reef-fishes, molluscs, and crustacea.

This is a wondrous natural world, almost unchanged by Man. Its remoteness, small land-area, and total lack of fresh water, have protected it. The Marshallese people are said to have regarded this atoll, and Bikar the next one lying to the south and likewise uninhabited by humans, in preEuropean times as sacred areas - sanctuaries for birds and sea-turtles. This status was made legal in a decree issued by the American District Administrator of the US Trust Territory of the Pacific. It has been a hope that this regulation would be continued and made law by the government of the new Republic of the Marshall Islands - which has given strong indications of a far-sighted wish to preserve, to the extent that proves practical, the biological diversity of these islands, and has had a survey team in the field to determine how best this can be done.

Such being the case, it was a great and disagreeable shock to see, in a local newspaper, the Marshall Islands Journal, 


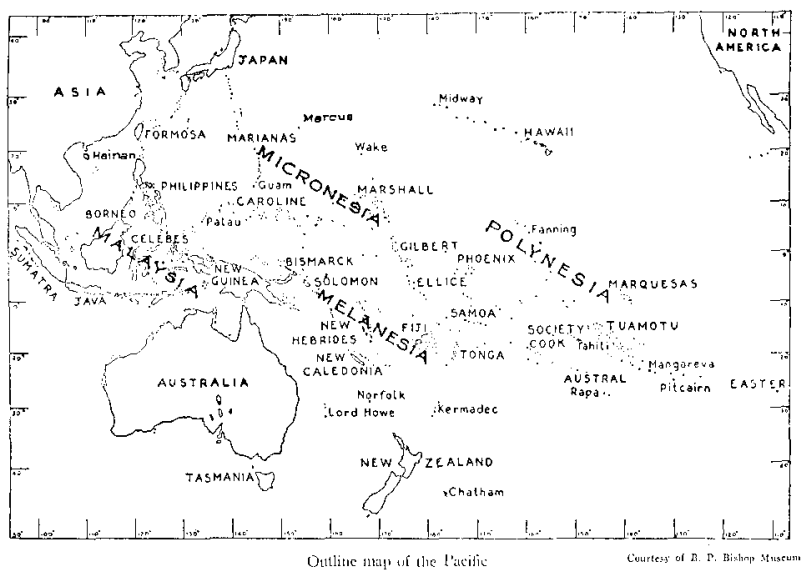

FIG. 3. General map of the Western Pacific.

dated September 1988, a lengthy, unsigned article entitled 'Garbage by the Ton?' That article described a plan, apparently well-advanced and agreed to by the Iroij, chief of this part of the Marshall group, to use this fascinating atoll as a gigantic 'landfill' or garbage dump. Its lagoon would be the receptacle of an estimated $25,000,000$ tons of solid waste 'biomass'[=garbage] a year, until the lagoon became filled.
Then the plan is to use the resulting new land to build a 'sports fishermen's retreat', including, for example, 'harbour, docks, boats, service facilities, hotel accommodation, golf course and other amenities'. It is stated that 'it is essential that the total development of the Ralik chain [of the Marshall Islands Figs 2 and 3] be paramount.'

We are assured that "no toxic or hazardous waste would be involved.' We are apparently expected to believe that the $25,000,000$ tons each year would be carefully sorted over to eliminate anything of this serious nature!

The profits to the corporation promoting this, from the first year's operation, are estimated to be 'more than $\$ 27$ millions'. If this operation were to prove successful, it would certainly only be a beginning of such desecration. The plan, as presented, only accounts for the waste from the western United States - a fraction of that produced by the world. Many more lagoons would eventually be needed.

We wonder if the people of the new Marshallese Republic would really care to think of their country as the world's garbage dump. Of course, for at least a few of them it would be profitable.

F. RAYMOND FosberG, Botanist Emeritus National Museum of Natural History

Smithsonian Institution

Washington

DC 20560, USA.

\section{The (British) Conservation Foundation}

\section{Aims and Launching}

The Conservation Foundation was established in 1982 to create and manage sponsorship schemes for all environmental interests.* The Foundation grew out of a scheme which had been created for the office equipment company Pitney Bowes entitled 'Elms Across Europe'. Using a strain of disease-resistant elm that had been developed in Wisconsin, this tree-planting campaign not only proved a great success for its sponsor but indicated to the company, and to Dr David Bellamy and the undersigned who created the campaign, that industry and commerce could be useful to help a variety of environmental causes.

The Foundation was launched at the Institute of Directors and was covered 'live' by BBC TV's 'Pebble Mill at One', who were involved with one of the Foundation's first schemes - the Ford Conservation Awards. Originally these awards, covering the natural environment, heritage, young people, and conservation engineering, were limited to the UK; but after two years they were extended into Europe and now involve fourteen countries. Another early sponsorship programme was the Community Chest scheme created for Trusthouse Forte. This gives grants to a wide range of local schemes aimed at improving their local environments.

\section{Breaking New Ground}

In gathering its sponsors the Conservation Foundation was anxious to break new ground by invoking companies that are not immediately involved with the environment, rather than such obvious ones as Shell or Imperial Chemical Industries. But getting support from the not-soinvolved was not easy. The Foundation's initial sponsors,

* See the welcoming note published in our Vol. 9, No. 1, Spring 1982, p. 9. -Ed.
Pitney Bowes, for example, were neither a household name nor involved in environmentally sensitive operations.

Meeting a new prospect's bankers, the undersigned explained the aims of the Foundation and reported Pitney Bowes' support. 'But why are they doing this?' enquired the banker, 'Pitney Bowes don't pollute the atmosphere, do they?'

But times change and now some seven years later the Foundation is developing environmental schemes for no less than three major banks. 'The first one to support us was the National Westminster, who sponsored our Environmental Entrepreneurs' Guide. We get a constant stream of ideas from people and inventors who still believe that with just a couple of thousand pounds, their idea could really take off. We have a guide-booklet which is very simple, but it means that we can give away something with some good examples, useful contacts, and a bit of advice; and every National Westminster Bank Manager has a stock of the Guide. We published the first edition of 10,000 during 1988 , and by the end of the year we were printing a second. It has been a great success and now the Bank want us to do more.

When a third bank contacted the Foundation, I explained our links with the National Westminster and another as yet remaining secret. The reply was 'Great - that makes my job much easier-it's much more difficult to get money out of my bosses to take the bank into a completely new area.'

\section{Mixed Bag of Ventures}

Since its beginning in 1982, the Foundation has got into a mixed bag of ventures-award schemes, board games, records, books, magazines, calendars, mail order, and newspaper appeals. Frequently we were travelling through uncharted waters, often without a great deal of support. Other environmental groups viewed the Foundation sus- 